\title{
The Effectiveness of Role-Playing Methods on Student's Critical Thinking Skills in "Interaction Between Creatures And Its Surroundings" Topic in Junior Highschool 1 Berbah
}

\author{
Ainun Khuluqun Adzim ${ }^{1}$ \\ ${ }^{1}$ Faculty of Mathematics and Natural Sciences, Universitas Negeri Yogyakarta \\ Corresponding Author. Email: 301.ainunadzim@gmail.com
}

\begin{abstract}
Keywords:

Critical Thinking

Skills, Role-

Playing Methods

The goal of This research are to understand the use role playing method impact on student's critical thinking skills and the effectiveness of role playing method on students' critical thinking skills. This research is a quasi-experimental study using a non-equivalent control group research design. The population of this research is all of class VII of SMP Negeri 1 Berbah in academic year 2020/2021. The sampling technique in this study uses the Cluster Random Sampling method. By using the random sampling cluster technique, carrying out the class selection for the sample randomly, class D was obtained as experimental class and class $\mathrm{C}$ was obtained as the control class. The experiment class was using role-playing methods while the controlled class was using conventional methods. The data collection instrument consisted of pretest and posttest questions of critical thinking skills. The pretestposttest score are used to obtain data for this study. The data analysis technique used are the prerequisite test in the form of normality and homogeneity tests and parametric statistical tests in the form of independent sample t-test, n-gain analysis and effect size. The results of this study showed that there is a significant effect in the use of role-playing methods on critical thinking skills of the students. From this study, it can be concluded that the role-playing methods are effective for the improvement of critical thinking ability of the students.
\end{abstract}

C2020 JSER. Yogyakarta State University

\section{INTRODUCTION}

Currently education in Indonesia uses the 2013 curriculum which is expected to be implemented in 21 st century learning. This serves to respond to the demands of an increasingly competitive era. The 21 st century learning reflects four things, namely communication, collaboration, critical thinking and problem solving, and creativity and innovation. These four things must be applied to the 2013 curriculum which is applied to the education system in Indonesia (Paryanti, 2017: 11).

However, based on observations made by researchers at SMP N 1 Berbah from June 24, 2019 to June 29, 2019, teachers still cannot maximize the critical thinking skills of students. This can be seen from students who only hear the teacher's explanation.
There is no exchange of opinion between teachers and students. When the teacher gives a question to students, students are less able to provide reasons or opinions related to the answers given. The answers given by students are only limited to memorizing them without having a fundamental concept.

The right learning method is to provide space for students to be actively involved in the learning process. But in the results of observations in June 2019, the learning method used still uses the lecture method where teacher-centered learning so that students are not actively involved in learning. The activities of students only listen and record what the teacher says, this results in low critical thinking skills of students.

By applying learning methods that are in accordance with the subject matter, students can easily understand 
what is being learned. One of them is the material for the interaction of living things and their environment. The characteristics of this material is that it is one of the science materials whose learning objects and sources are related to the surrounding environment, so that to study the material it is necessary to involve students with nature directly. However, the application of this observation method is less effective because not all interactions of living things can be seen clearly such as in the food chain submaterials and the interaction patterns of living things. In addition, for schools that are in a densely populated environment such as schools in urban areas, the objects to be observed are also very limited. It was proven at the time of observation that SMP N 1 Berbah was located on the side of a highway that did not allow students to make observations outside the classroom.

Based on the characteristics of the material for the interaction of living things and their environment, the researcher wants to apply the role playing method in which this method can bring students into the atmosphere of the interaction of living things without having to present the actual interaction. Hamalik (2004: 214) says that the advantage of the role playing method is that it provides opportunities for students to carry out active learning activities and learners learn based on their own experiences so that they have a strong and long lasting impression in the memories of students. In addition, the role playing method is considered effective for improving students' critical thinking. This is in accordance with the theory according to Zuhairini (1993: 89) which states that the role playing method is a method that is able to spur motivation, activeness, creativity and critical attitudes of students in learning activities. Therefore, the researcher wants to apply the role playing method to improve the critical thinking skills of students so that it can be a solution to solving learning problems in class VII SMP N 1 Berbah.

\section{METHOD}

This type of research is quasi experimental. The research was conducted at SMP Negeri 1 Berbah which was conducted during January 2020. The population of this research was all class VII SMP N 1 Berbah which consisted of 4 classes, namely class VII A, VII B, VII C, and VII D. The research sample was taken in the study. This method uses cluster random sampling technique, so that the sample class VII C and class VII D SMP Negeri 1 Berbah were obtained. This type of research is a quasi experiment. The design used in this study is to use the nonequivalent control group design. The form of the research design is shown in table 1 .
Table 1. Design Nonequivalent Control Group Design.

\begin{tabular}{cccc}
\hline Group & Pre-Test & Treatment & Post Test \\
\hline Experiment & $\mathrm{V}_{1}$ & $\mathrm{O}$ & $\mathrm{V}_{2}$ \\
Control & $\mathrm{V}_{1}$ & $\mathrm{X}$ & $\mathrm{V}_{2}$ \\
\hline
\end{tabular}

Explanation:

O: Learning with the role playing method

$\mathrm{X}$ : Learning with the lecture method

The data collection technique in this research is using tests. The test technique uses an essay question in the form of a pretest and posttest critical thinking skills, which consists of 5 questions.

The data analysis technique in this study consists of a prerequisite test of the hypothesis and hypothesis testing. The prerequisite test consists of a normality test and a homogeneity test. Hypothesis testing is used in the form of independent sample $t$ test, n-gain analysis and effect size.

Independent Sample T-Test is a comparative test or different test to find out whether there is a significant difference in mean between 2 unpaired independent groups (Rosana \& Didik, 2016: 76). In this study, it was used to see the difference in the mean critical thinking skills between classes using the role playing method and those using the lecture method.

\section{Research Hypothesis:}

Ho: There is no significant difference in the critical thinking skills of students between classes that use role playing methods and classes that use the lecture method.

H1: There is a significant difference in the critical thinking skills of students between the class that uses the role playing method and the class that uses the lecture method.

Terms:

If Sig. (2-tailed) $\geq 1 / 2 \alpha(0.025)$, then $\mathrm{Ho}$ is accepted. If Sig. (2-tailed) $<1 / 2 \alpha(0.025)$, then Ho is rejected.

$\mathrm{N}$-gain functions to determine the increase in the posttest and pretest scores before being treated with after being given treatment. The $\mathrm{N}$-gain can be calculated by the equation:

$$
\text { indeks gain }(g)=\frac{\text { posttest }- \text { pretest }}{\text { skor maksimum - pretest }}
$$

Table 2. N-Gain classification (g)

\begin{tabular}{cl}
\hline Value $(\mathrm{g})$ & \multicolumn{1}{c}{ Interpretation } \\
\hline $0,7<\mathrm{g}$ & Tinggi \\
$0,3<\mathrm{g}<0,7$ & Sedang \\
$\mathrm{g}<0,3$ & Rendah \\
\hline & (Meltzer, 2002: 1260)
\end{tabular}


The effect size test was conducted to determine the significance level of the sample from the two groups. The effect size can be calculated by the equation:

Explanation :

$$
d=\frac{X 1-X 2}{S_{g a b}}
$$

d: effect size

$\mathrm{X} 1$ : the average of the experimental class

$\mathrm{X} 2$ : average control class

Sgab: combined standard deviation

$$
S_{g a b}=\sqrt{\frac{\left(N_{E}-1\right) S D_{E}{ }^{2}+\left(N_{k}-1\right) S D_{k}{ }^{2}}{N_{E}+N_{K}-2}}
$$

Explanation

NE: number of experimental samples

Nk: number of control samples

SDE: the standard deviation of the

experiment

SDK: standard deviation of control

(Cohen, Manion, \& Morrison, 2011: 617).

Furthermore, the results of the effect size obtained are interpreted into categories with the criteria according to table 3 below.

Table 3. Effect size criteria

\begin{tabular}{|c|c|}
\hline Scale & Criteria \\
\hline $\mathrm{d}>1,00$ & Very strong \\
\hline $0,51 \leq \mathrm{d} \leq 1,00$ & Strong \\
\hline $0,21 \leq \mathrm{d} \leq 0,51$ & Moderate \\
\hline $0,00 \leq \mathrm{d} \leq 0,20$ & Weak \\
\hline
\end{tabular}

(Cohen, Manion, \& Morrison, 2011:617).

\section{RESEARCH RESULTS AND DISCUSSION}

The research entitled "The Effectiveness of the Use of Role Playing Methods on Students' Critical Thinking Ability on the Interaction of Living Things and Their Environment in SMP Negeri 1 Berbah. This study aims to determine the significant effect of the use of the role playing method on students 'critical thinking skills and to determine whether or not the use of role playing methods is effective on students' critical thinking skills.

The implementation of the role playing method in the experimental class was held 3 times. The first meeting aims to explain the environmental component submaterial. Students play a role as a biotic component and an abiotic component. The second meeting aims to explain the food chain submaterials and food webs. Learners portray living beings involved in food chains and food webs. The third meeting aims to explain submaterial interaction patterns of living things. Students act out the interactions of living things, including symbiosis, predation, and competition.

The data used in this research is the pretest-posttest value of critical thinking skills that have been done by students. The pretest-posttest questions consisted of 5 essay items that had been validated both theoretically and empirically. These questions include 5 indicators of critical thinking, namely solving problems, interpreting, analyzing, evaluating, and drawing conclusions. The data that has been obtained are then analyzed with the help of SPSS and Ms. Excel. The average pretest and posttest scores for the control and experimental classes can be seen in Figure 1.

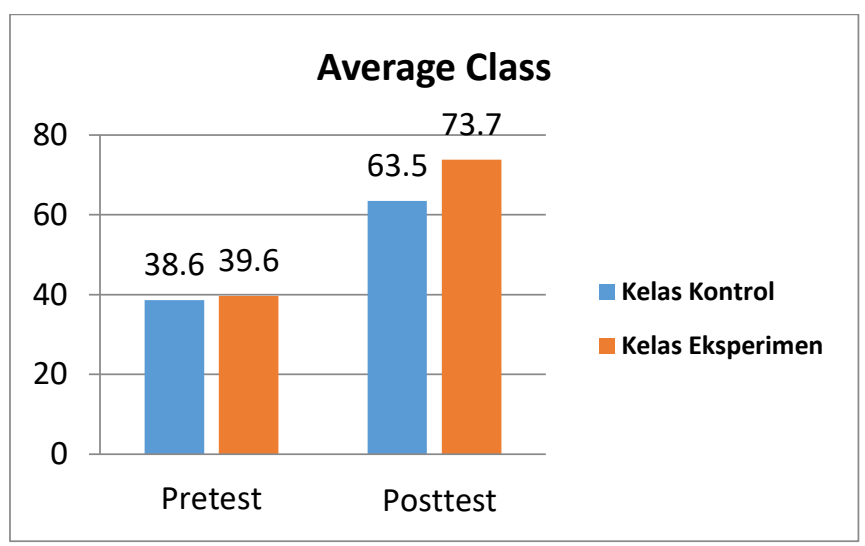

Figure 1. Average Pretest and Posttest Scores

Based on Figure 1, it can be seen that the initial abilities of students, both the control class and the experimental class, have an average score that is not too different. The control class has an average score of 38.6 while the experimental class has an average score of 39.6. However, the posttest scores, the control class and the experimental class have an average score that is far apart, namely 63.5 for the control class and 73.7 for the experimental class.

Furthermore, N-gain analysis is carried out to determine the magnitude of the increase in critical thinking skills. The $\mathrm{N}$-gain analysis can be seen in Figure 2.

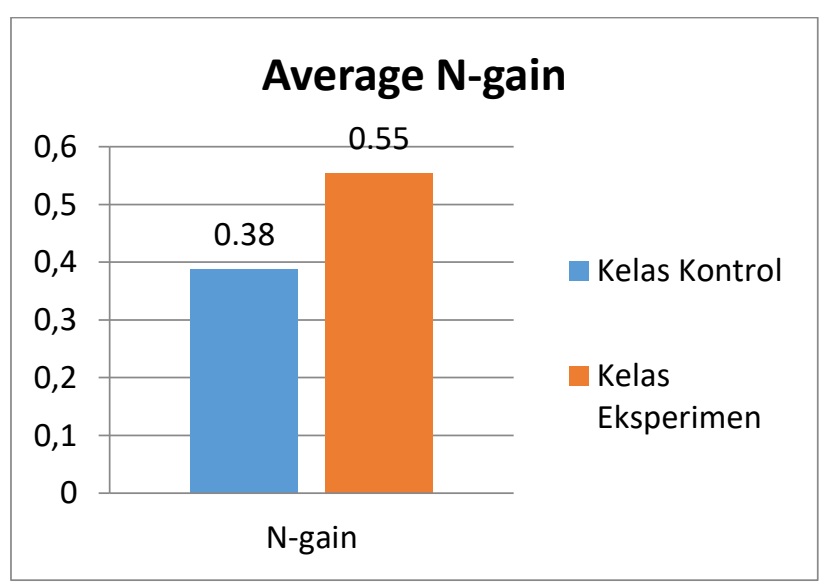

Figure 2. Comparison of the N-gain PretestPosttest

In Figure 2 it can be seen that the N-gain in the control class is 0.38 and the $\mathrm{N}$-gain in the experimental class is 0.55 . From these data it is known that the control class and the experimental 
class are all included in the medium category. However, when compared to the $\mathrm{N}$-gain value, the experimental class was bigger than the control class by a difference of 0.16 . So it can be said that the increase in critical thinking skills in the experimental class is higher than the control class. This is in accordance with Zuhairini's (1993: 89) theory which states that the role playing method is a method capable of spurring motivation, activeness, creativity and critical attitudes of students in learning activities.

Furthermore, the pretest-posttest score was carried out by a prerequisite test in the form of a homogeneity test and a normality test. After the prerequisite test is met, namely the data is normally distributed and is homogeneous, the data can be analyzed using the Independent Sample T-test where if the score is Sig. (2-tailed) $<1 / 2 \alpha(0.025)$, then $\mathrm{Ho}$ is rejected. Based on the Independent Sample T-test using the SPSS 22 application, the following results were obtained:

Table4. Result of Independent Sample T-test

\begin{tabular}{|c|c|c|c|}
\hline \multirow{2}{*}{ Data } & \multicolumn{3}{|c|}{ T-test for equality of means } \\
\cline { 2 - 4 } & $\mathrm{t}$ & $\mathrm{Df}$ & Sig. (2-tailed) \\
\hline$N$-gain & $-3,778$ & 64 & 0,000 \\
\hline
\end{tabular}

Based on Table 4, it can be seen that the Sig. (2-tailed) value is smaller than $1 / 2 \alpha(0.025)$ with a value of 0,000 . So Ho is rejected so that there is a significant difference in the critical thinking skills of students between the class using the role playing method and the class using the lecture method.

Then to determine the magnitude of the influence of using the role playing method, it can be seen by the effect size analysis. The calculation of the effect size on critical thinking skills is 0.93 which is included in the strong category. From these results it can be seen that the magnitude of the influence of using role playing methods on critical thinking skills is included in the strong category.

The results of observations when learning took place, it was seen that students who used the role playing method were more active in expressing their opinions and were able to refute statements that were not appropriate compared to the control class who used the lecture method. In the control class, students are more passive. If there is a statement that is not appropriate, no student can argue with that statement. So that students in the control class tend to only accept the material. Meanwhile, the experimental class seemed very enthusiastic about the learning that was followed. These results are in accordance with Aris Shoimin (2014: 162) who says that the role playing method has several advantages, including that students are free to make decisions and express themselves as a whole, have a strong and long lasting impression on students' memories, are very attractive to students so that they allow the class be dynamic and full of enthusiasm.

From some of the results of the analysis that has been done, it can be seen that learning using the role playing method is effective in increasing students' critical thinking skills compared to learning using the lecture method. This is in accordance with the statement of Relita (2015: 5) in her research which states that in the experimental class after receiving the role playing method treatment, it was proven to be effective in increasing the critical thinking skills of students compared to control class students who used conventional methods.

\section{CONCLUSION}

The conclusions in this study are (1) There is a significant influence on the use of the role playing method on the critical thinking skills of students. (2) The method of role playing is effective at increasing the critical thinking skills of students compared to the lecture method.

\section{REFERENCES}

Aris Shoimin. (2014). 68 Model Pembelajaran Inovatif dalam Kurikulum 2013. Yogyakarta: Ar Ruzz Media.

Cohen, L., Manion, L., \& Morrison, K. (2011). Research Methods in Education (6 $6^{\text {th }}$ ed.). London, New York: Routllege Falmer.

Emzir. (2015). Metodologi Penelitian Pendidikan: Kuantitatif dan Kualitatif. Jakarata: Rajawali Pers.

Hamalik, Oemar. (2004). Proses Belajar Mengajar. Jakarta: Bumi Aksara.

Meltzer, D.E. (2002). The Relationship between Mathematics Preparation and Conceptual Learning Gains in Physics: a Possible "Hidden Variable" in Diagnostic Pretest Score. American Journal of Physics. Vol. 70 (12), 1259-1268.

Rosana, D., \& Setyawarno, D. (2016). Statistik Terapan untuk Penelitian Pendidikan. Yogyakarta: UNY Press.

Paryanti, E. (2017). Pengaruh Faktor Budaya, Sosial dan Pribadi Terhadap Keputusan Pembelian Action Camera Gopro (Studi Pada Pengunjung Obyek Wisata Waduk Wonorejo Tulungagung). SimkiEconomic Vol. 01 No. 03 Tahun 2017 ISSN. 
Relita, Dessy Triana. (2015). Penerapan Metode Role playing Terhadap Kemampuan Berpikir Kritis Peserta didik Pada Mata Pelajaran Ekonomi. Jurnal Ilmiah. 5.

Zuhairini. (1993). Metodologi Pendidikan Agama. Solo: Ramdhan. 